Brit. J. vener. Dis. (1962), 38, 200.

\title{
POSSIBLE VIRUS AETIOLOGY OF NON-SPECIFIC
}

\section{URETHRITIS*}

\author{
BY \\ M. JOAN WHITTINGTON \\ The London Hospital
}

The simplest classification of cases of urethritis is a broad division into the gonococcal and nongonococcal varieties. The non-gonococcal group includes a number of conditions in which a cause is identifiable, such as Trichomonas vaginalis, chemical irritants, and strictures or diseases of the upper renal tract, but these and other cases form only a small proportion of the group, and the cause of the commonest variety, usually termed non-specific urethritis, remains undiscovered. On epidemiological grounds, non-specific urethritis is usually considered to be due to an infection. In recent years much attention has been given to the role played by pleuro-pneumonialike organisms, but there is as yet no proof of their pathogenicity in the human urogenital tract in a majority of cases. It has frequently been suggested that the disease is caused by a virus, the presumptive evidence of such a cause being the discovery of inclusion bodies in the urethral cells of men with urethritis (Lindner, 1910; Thygeson and Mengert, 1936; Thygeson and Stone, 1942; Siboulet, 1955). These bodies resemble the intracellular inclusions produced by the larger "viruses" of the trachomalymphogranuloma venereum group, and appear to be morphologically very similar to those found in the conjunctival epithelial cells of babies with inclusion blennorrhoea and in the cervical epithelium of women. The production of inclusion conjunctivitis in baboons inoculated with secretions (in which inclusions had been demonstrated) from men with urethritis, women with cervicitis, and babies with conjunctivitis (Fritsch, Hofstätter, and Lindner, 1910) suggests a relationship between these three conditions. Although the virus of inclusion conjunctivitis has been isolated from the cervices of women (Jones, Collier, and Smith, 1959) and from the eye of a baby (Reed, 1961,

* Received for publication July 2, 1962. personal communication), there are no records of its recovery from the male urogenital tract. The number of cases of urethritis in men due to this cause may be small-Siboulet (1955) found inclusions in only 3 per cent. of 2,756 stained smears from the cases which he examined.

It is possible that the causative organism of nonspecific urethritis, if a virus, may be quite different in nature from the members of the trachoma-L.G.V.inclusion conjunctivitis group, and may require different techniques for its detection and isolation. In recent years improvements in tissue culture methods have made possible the isolation of many new viruses. Although attempts by Ford $(1956 ; 1958)$ and Csonka and Furness (1960) to isolate a virus from the genital tracts of men with non-gonococcal urethritis using tissue cultures were unsuccessful, it was felt that further investigations in this field were worth pursuing, and the work described in this paper was undertaken for this reason. Although no virus was isolated from any of the patients examined, it was thought worthwhile to record the negative results and to describe the methods used, in the hope that further work on this intriguing subject may be stimulated, and that the repetition of what have proved to be unrewarding lines of investigation may be prevented.

\section{Clinical Material}

As the nature of the hypothetical virus was unknown, it was decided that a detailed examination of specimens from a few patients would be the most suitable method of approach. Later, if one particular line of attack seemed promising, attention could be concentrated on this method, the investigation simplified, and the number of patients examined increased. 
Twenty white male patients attending the Whitechapel Clinic of the London Hospital between June, 1960, and April, 1961. provided the material for this study. The cases investigated were men with clinically typical non-specific urethritis. In most cases the urethritis was uncomplicated, but a few of the men had other disorders as well (see Table I). Coloured patients were not included, because, although this disease is common among coloured men, it is our experience that white patients are less likely to default. White patients who seemed unlikely to attend for follow-up were also excluded. The length of time and amount of work involved in examining each specimen further reduced the number of patients which could be included in the series.

Clinical details of the twenty patients are given in Table I (overleaf).

\section{Collection of Specimens}

After a smear had been made from the urethral discharge and examined for gonococci, and a specimen for culture of these organisms had been taken, the meatus was cleaned with spirit and dried, and the urethral mucosa was scraped with a platinum loop. One loopful of the exudate was placed in Trichomonas vaginalis culture medium (Feinberg and Whittington, 1957), and further specimens were spread on clean glass slides. One smear was examined for trichomonads while it was still wet, another was fixed in methyl alcohol for staining with Giemsa later, and three more were air-dried. As this amount of urethral scraping caused discomfort in some of the patients, only two smears were made in Cases 9 to 20 -a fresh preparation for examination for $T$. vaginalis, and one dried smear. $5 \mathrm{ml}$. sterile Hanks's solution (Hanks, 1949) were introduced into the urethra and then ejected into a sterile bottle. Cultures for $T$. vaginalis were made in the last twelve cases from the centrifuged deposit of urine voided after the urethral washout. Cultures for pleuro-pneumonia-like organisms were made in PPLO medium (Klieneberger-Nobel, 1959) from the centrifuged deposit of part of the urethral washing in Cases 1 to 8, but to conserve as much of the washing as possible for the cell cultures, the centrifuged urine deposit was used for PPLO culture in Cases 9 to 20.

\section{Laboratory Procedure}

\section{(i) Staining Methods for Urethral Smears}

GIEMSA. - The smear which had been fixed in methyl alcohol was stained in diluted Giemsa (1 drop of stain to $1 \mathrm{ml}$. buffer at $\mathrm{pH}$ 7), dried, and mounted. By this method, cytoplasmic inclusions produced by viruses of the trachoma-LGV group stain deep purple, and contrast well with the pale blue cytoplasm of the epithelial cells.

IoDiNe. - As these inclusions stain dark brown with iodine and can easily be distinguished from the pale yellow cellular material, one dry smear was treated with a solution of 5 per cent. iodine in 10 per cent. potassium iodide for 15 minutes, dried, and examined microscopically with the $\frac{1}{12}$ in. oil-immersion objective. As only one dried smear was available for study from Cases 9 to 20, this was stained first with iodine and then, when the oil had been removed and the iodine washed out, it was stained with Giemsa (Gilkes, Smith, and Sowa, 1958).

CASTANEDA. - A few dried urethral smears were heat-fixed and stained by the following modification of Castaneda's method:

Stain preparations in formol blue* for 5 minutes; rinse with 0.25 per cent. aqueous sofranin to differentiate and counterstain; rinse quickly in tap water and blot dry.

By this technique, viral particles of the trachoma group can be demonstrated, as they stain deep violet in colour.

\section{(ii) Virus Culture Methods for Urethral Washings}

Two sources of living cells were chosen for the attempted isolation of viruses: embryonated hens' eggs and tissue cultures.

EGGS. - 5- to 7-day-old eggs were inoculated by the yolk sac route. This method having been used successfully in isolating LGV and inclusion conjunctivitis viruses, it was hoped that the latter, if present in the urethra, would be detected.

$0.25 \mathrm{ml}$. urethral washing was introduced into each of four eggs. The inoculated eggs were incubated at temperatures ranging from $31 \cdot 6^{\circ}$ to $36 \cdot 6^{\circ} \mathrm{C}$., transilluminated, and turned daily. They were opened when the embryo died or, if it remained alive, shortly before it was due to hatch. Impressions of the yolk sac stained by Gram's and Castaneda's methods were examined for bacteria and virus particles respectively and, when anything suggesting the latter was seen, the yolk sacs were removed, placed in hypotonic buffer solution, and ground in a Ten Broeck tube, and the suspension was passed to more

\footnotetext{
* FORMOL BLUE: 5 parts 1 per cent. Azur II in methyl alcoho plus 95 parts of the following mixture: $100 \mathrm{ml}$. $\mathrm{M} / 15 \mathrm{KH}_{2} \mathrm{PO}_{4}$ plus $59 \cdot 36 \mathrm{ml}$. M/15 NaOH plus $4.5 \mathrm{ml}$. formalin.
} 
CLINICAL DATA OF TWENTY PATIENTS

\begin{tabular}{|c|c|c|c|c|c|c|}
\hline \multirow[b]{2}{*}{ Case No. } & \multirow[b]{2}{*}{ Age (yrs) } & \multirow[b]{2}{*}{ Diagnosis } & \multicolumn{2}{|c|}{ Previous History of Genital Disease } & \multicolumn{2}{|c|}{ Present II $\underset{\sim}{\bar{n}}$} \\
\hline & & & Disease & Treatment & Symptoms & $\begin{array}{c}\overline{\bar{ज}} \\
\text { Duration } \\
\text { (daqs) }\end{array}$ \\
\hline 1 & 18 & NSU & Nil & Nil & Urethral Discharge & $\frac{\bar{g}}{\bar{\alpha}}$ \\
\hline 2 & 20 & NSU & Nil & Nil & Urethral Discharge & 远 \\
\hline \multirow{3}{*}{3} & \multirow{3}{*}{18} & \multirow{3}{*}{$\begin{array}{l}\text { NSU and } \\
\text { Abacterial } \\
\text { Cystitis }\end{array}$} & \multirow{3}{*}{ Nil } & \multirow{3}{*}{ Nil } & Urethral Discharge & 4 \\
\hline & & & & & Frequency of micturition & $P$ \\
\hline & & & & & Haematuria & $1 \sigma$ \\
\hline 4 & 20 & NSU & Nil & Nil & Urethral Discharge & 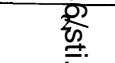 \\
\hline \multirow{2}{*}{5} & \multirow{2}{*}{24} & \multirow{2}{*}{ NSU } & \multirow{2}{*}{ Nil } & \multirow{2}{*}{ Nil } & Dysuria & $\$$ \\
\hline & & & & & Urethral Discharge & 6 \\
\hline 6 & 51 & $\begin{array}{l}\text { Recurrent } \\
\text { NSU }\end{array}$ & $\begin{array}{l}\text { Recurrent urethral discharge } \\
\text { for past } 21 \mathrm{mths}\end{array}$ & $\begin{array}{l}\text { Various } \\
\text { Last Spiramycin } 6 \text { wks before }\end{array}$ & Urethral Discharge & $\begin{array}{l}8 \\
0 \\
0\end{array}$ \\
\hline \multirow{3}{*}{7} & \multirow{3}{*}{21} & \multirow{3}{*}{$\begin{array}{l}\text { Reiter's } \\
\text { Syndrome }\end{array}$} & \multirow{3}{*}{ Nil } & \multirow{3}{*}{ Nil } & $\begin{array}{l}\text { Joint pain } \\
\text { Conjunctivitis }\end{array}$ & 10-开 \\
\hline & & & & & Urethral Discharge & $18 \mathrm{D}$ \\
\hline & & & & & $\begin{array}{l}\text { Dysuria } \\
\text { Slight frequency }\end{array}$ & $\frac{2 \mathrm{DO}}{3}$ \\
\hline 8 & 26 & NSU & Nil & Nil & $\begin{array}{l}\text { Urethral Discharge } \\
\text { Irritation }\end{array}$ & $\stackrel{D}{-1}$ \\
\hline 9 & 32 & NSU & $\begin{array}{l}\text { Two attacks of NSU } 5 \text { yrs } \\
\text { before }\end{array}$ & $\begin{array}{l}\text { Streptomycin and Sulpha- } \\
\text { triad } 5 \text { yrs before }\end{array}$ & $\begin{array}{l}\text { Urethral Discharge } \\
\text { Irritation }\end{array}$ & రृ \\
\hline 10 & 21 & NSU & NSU 2 yrs before & $\begin{array}{l}\text { Streptomycin and Sulpha- } \\
\text { triad } 2 \text { yrs before }\end{array}$ & $\begin{array}{l}\text { Urethral Discharge } \\
\text { Dysuria }\end{array}$ & 亟 \\
\hline 11 & 24 & NSU & Nil & Nil & $\begin{array}{l}\text { Urethral Discharge } \\
\text { Frequency of micturition }\end{array}$ & 21 อัด \\
\hline 12 & 44 & NSU & $\begin{array}{l}\text { Three attacks of NSU in } \\
\text { past } 8 \mathrm{mths}\end{array}$ & $\begin{array}{l}\text { Streptomycin and SMP for } \\
\text { each attack }\end{array}$ & $\begin{array}{l}\text { Urethral Discharge } \\
\text { Slight dysuria }\end{array}$ & $\frac{2}{8}$ \\
\hline 13 & 36 & NSU & Nil & Nil & $\begin{array}{l}\text { Urethral Discharge } \\
\text { Slight irritation }\end{array}$ & $4-\frac{5}{3}$ \\
\hline 14 & 24 & NSU & Nil & Nil & Urinary Irritation & 证 \\
\hline 15 & 26 & NSU & ?NSU 5 yrs before & Not known & Urethral Discharge & 1\% \\
\hline 16 & 30 & NSU & Nil & Nil & $\begin{array}{l}\text { Urethral Discharge } \\
\text { Slight irritation on mic- } \\
\text { turition }\end{array}$ & 힐. \\
\hline \multirow[t]{2}{*}{17} & \multirow[t]{2}{*}{25} & \multirow[t]{2}{*}{ NSU } & NSU 6 yrs before & $\begin{array}{l}\text { Streptomycin and Sulpha- } \\
\text { diazine }\end{array}$ & \multirow{2}{*}{$\begin{array}{l}\text { Urethral Discharge } \\
\text { Slight dysuria }\end{array}$} & 3 \\
\hline & & & Balanitis 2 yrs before & Nil & & 음 \\
\hline 18 & 23 & NSU & NSU 13 mths before & Terramycin & Urethral Discharge & 变 \\
\hline 19 & 29 & NSU & Nil & Nil & Urethral Discharge & $7 \mathrm{~N}$ \\
\hline 20 & 19 & NSU & Nil & Nil & $\begin{array}{l}\text { Urethral Discharge } \\
\text { Dysuria }\end{array}$ & ${ }^{7} \mathrm{O}$ \\
\hline \multicolumn{3}{|c|}{$\begin{array}{l}\text { NSU }=\text { Non-specific urethritis. } \\
\text { SMP }=\text { Sulphamethoxypyridazine. }\end{array}$} & $\begin{array}{l}\text { Staph. = Staphylococci. } \\
\text { Diph. = Diphtheroids. }\end{array}$ & $\begin{array}{l}\text { Colif. } \\
\text { Strep. }\end{array}$ & $\begin{array}{l}=\text { Coliforms. } \\
=\text { Streptococci. }\end{array}$ & 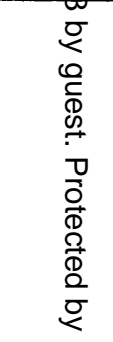 \\
\hline
\end{tabular}


NON-SPECIFIC URETHRITIS

\begin{tabular}{|c|c|c|c|c|c|c|c|}
\hline \multirow{3}{*}{$\begin{array}{l}\text { Nature of } \\
\text { Urethral Discharge }\end{array}$} & \multicolumn{2}{|c|}{ Interval (days) between Last Sexual Intercourse and: } & \multicolumn{5}{|c|}{ Urethral Pathology } \\
\hline & \multirow{2}{*}{ Onset of Illness } & \multirow{2}{*}{ Taking of Specimen } & \multirow{2}{*}{ Pus* } & \multicolumn{2}{|c|}{ Bacteria } & \multirow{2}{*}{ PPLO } & \multirow{2}{*}{$\begin{array}{l}\text { Trichomonas } \\
\text { vaginalis }\end{array}$} \\
\hline & & & & Smeart & Culture & & \\
\hline Moderate, thick & 15 & 17 & 20 & - & $\begin{array}{l}\text { Staph. } \\
\text { Diph. }\end{array}$ & + & - \\
\hline Thin & (Multiple & Exposures) & 20 & - & Staph. & - & - \\
\hline Profuse, white & \multicolumn{2}{|c|}{ Denied Intercourse } & 20 & - & $\begin{array}{l}\text { Staph. } \\
\text { Colif. }\end{array}$ & - & - \\
\hline Profuse, mucoid & ? (Multiple & Exposures) $?$ & 15 & \pm & $\begin{array}{l}\text { Staph. } \\
\text { Colif. }\end{array}$ & - & - \\
\hline Profuse, watery & 18 & 24 & $15-20$ & + & Staph. & - & - \\
\hline Profuse & 665 & 665 & 20 & \pm & Staph. & - & - \\
\hline $\begin{array}{l}\text { Moderate, } \\
\text { muco-purulent }\end{array}$ & \multicolumn{2}{|c|}{ Denied Intercourse } & 20 & - & $\begin{array}{l}\text { Not } \\
\text { recorded }\end{array}$ & - & - \\
\hline $\begin{array}{l}\text { Moderate, } \\
\text { nuco-purulent }\end{array}$ & $\begin{array}{c}1 \\
\text { (Previous Exposur }\end{array}$ & re 13 days before) & 20 & + & $\begin{array}{l}\text { Staph. } \\
\text { Diph. }\end{array}$ & - & - \\
\hline Slizht, whitish & 2 & 4 & 15 & \pm & $\begin{array}{l}\text { Staph. } \\
\text { Diph. }\end{array}$ & - & - \\
\hline Mıcoid & $9-10$ & $13-14$ & 20 & - & $\begin{array}{l}\text { Staph. } \\
\text { Diph. }\end{array}$ & - & - \\
\hline $\begin{array}{l}\text { Profuse, } \\
\text { muco-purulent }\end{array}$ & 7 & 28 & 20 & - & Staph. & - & ${ }^{-}$ \\
\hline Purulent & 12 & 14 & 20 & \pm & $\begin{array}{l}\text { Staph. } \\
\text { Diph. }\end{array}$ & - & - \\
\hline$W_{\text {atery }}$ & 4 & $8-9$ & $5-10$ & \pm & $\begin{array}{l}\text { Staph. } \\
\text { Diph. }\end{array}$ & - & - \\
\hline Scanty, mucoid & 6 & 48 & 20 & + & $\begin{array}{l}\text { Staph. } \\
\text { Diph. }\end{array}$ & - & - \\
\hline Not recorded & 3 & 4 & 20 & - & $\begin{array}{l}\text { Staph. } \\
\text { Diph. }\end{array}$ & - & - \\
\hline Muco-purulent & \multicolumn{2}{|c|}{$\begin{array}{c}13 \\
\text { (Previous Exposure 35 days before) }\end{array}$} & 20 & - & Staph. & - & + \\
\hline Watery & 11 & 14 & 20 & \pm & $\begin{array}{l}\text { Colif. } \\
\text { Diph. }\end{array}$ & - & - \\
\hline Watery & 20 & 21 & 15 & \pm & $\begin{array}{l}\text { Staph. } \\
\text { Strep. }\end{array}$ & - & - \\
\hline Purulent & 14 & 21 & 20 & - & Diph. & - & - \\
\hline Purulent & 7 & 14 & 20 & - & $\begin{array}{l}\text { Staph. } \\
\text { Colif. }\end{array}$ & - & - \\
\hline
\end{tabular}

* No. cells per $1 / 12$ inch oil immersion field. " $20 "=20$ or more. $\quad++=$ moderate number of bacteria present in Gram-stained smear. 
eggs. The passes were sometimes made directly after the yolk sacs were removed, but as the embryos died at different times the usual procedure was to keep the yolk sacs in buffer at $+4^{\circ} \mathrm{C}$. and select the most promising for passage.

Tissue Cultures. - These were all of human origin and comprised one established line - HeLa (Gey, Bang, and Gey, 1954) and several freshlyisolated types, as the range of susceptibility to viruses differs in established lines and in freshly-isolated cells. At the beginning of the investigation, cultures of freshly prepared human amnion and human thyroid cells were used; later these were replaced by human foetal cell cultures (kidney and lung).

The stock strain of HeLa cells was subcultured weekly, and the requisite number of small culture tubes prepared as required for the experiments. Trypsinized suspensions of thyroid, amnion, and foetal cells were made by the method of Pulvertaft (Pulvertaft, Davies, Weiss, and Wilkinson, 1959).

The HeLa, thyroid, and foetal cells were grown in Hanks's balanced salt solution, containing 0.042 per cent. sodium bicarbonate, $0 \cdot 25$ per cent. lactalbumen hydrolysate, 5 per cent. digest broth, 5 per cent. horseserum, 5 per cent. rabbit-serum, $200 \mu \mathrm{g}$. streptomycin per ml., and phenol red to indicate the $\mathrm{pH}$. For the amnion cells which grew more slowly, the percentage of horse-serum was increased to 15 or 20 . All the cell cultures contained coverslips and $1.5 \mathrm{ml}$. tissue culture medium, and were incubated at $32^{\circ}$ to $36^{\circ} \mathrm{C}$., the tubes being inclined at an angle of $5^{\circ}$ from the horizontal. When monolayers of cells had formed on the glass (this occurred in 1 to 3 days with the HeLa cells, 2 to 3 days with thyroid and foetal lung cells, and 5 to 9 days with amnion and foetal kidney cells), the growth medium was replaced with an equal volume of maintenance medium, containing less serum ( 2 per cent.) and more bicarbonate ( 0.084 per cent.). The cultures were then ready for inoculation with the urethral washings.

0.1 to $0.3 \mathrm{ml}$. washing was added to each of three of the various types of cell culture; an equal number of uninoculated tubes provided the controls. The inocula from Cases 1 to 10 were added to the maintenance medium already in the tubes, and these were rotated on a roller machine (12 revolutions an hour) for the first few hours of incubation to increase the chance of virus particles coming into contact with the cells. The cultures were kept stationary for the remainder of the incubation period. It was later decided that a better way of bringing the virus into contact with the cells would be to remove the medium from the culture tubes, add $0 \cdot 3-\mathrm{ml}$. amounts of the inoculum to the cell sheets, incubate the cells for 1 hour, and then add fresh maintenance medium. This method was adopted for the specimens from Cases 11 to 20 .

Using a $\frac{2}{3}$ in. objective, the living cells were examined in situ under the microscope for cytopathic changes. They were observed daily during the first week after inoculation, and twice weekly during the rest of the incubation period. In order to study cellular detail, coverslips were removed at intervals from control and inoculated tubes, fixed in 95 per cent. ethyl alcohol (an excellent fixative for this purpose), and cut in half; one part was stained with dilute Giemsa and the other with Harris's haematoxylin and eosin. The culture medium was changed when it tended to become acid.

At least one pass was made from the inoculated cell cultures to new cell cultures of the same type, except when bacterial contamination made this impossible. Previous experience had shown that a cytopathic effect (CPE) due to a virus might take some time to appear, so the cultures were not discarded until the cells in both control and inoculated tubes were markedly degenerate and falling off the glass. This time varied from 9 to 18 days for the HeLa cell cultures and from 4 to 5 weeks for the amnion cultures. The thyroid and foetal cells survived for 2 to 4 weeks.

In order to reproduce as closely as possible the natural conditions in which a virus might live in the genital tract, the $\mathrm{pH}$ and the temperatures of the urethrae of the first nine patients were measured. The reaction was alkaline in all cases, ranging from 7.9 to $8 \cdot 8$, and the temperatures were below normal $-31 \cdot 6^{\circ}$ to $36 \cdot 6^{\circ} \mathrm{C}$. The inoculated cell cultures and eggs were incubated at temperatures within this range, and the cell culture fluid was kept on the alkaline side $(\mathrm{pH} 7 \cdot 4$ or above).

\section{(iii) Pre-treatment of Urethral Washings}

It was assumed that the chances of detecting a virus would be increased if the urethral secretions were put into eggs and cell cultures as soon as the specimens had been taken from the patient. The effects of storage at $-72^{\circ} \mathrm{C}$. were unknown; presumably some of the virus would be destroyed by this treatment, so fresh washings were used where possible. However, the bacteria present in the secretions proved a major obstacle to this ideal procedure, and some of the washings from the first twelve patients were kept at $-72^{\circ} \mathrm{C}$. for 2 to 3 days until the sensitivities to antibiotics of the associated bacteria were known. 
Two ways of preventing bacterial contamination were tried-adding antibiotics to the specimens, and filtering them. A reduction in the amount of virus present would probably occur in using either of these methods, but as no better practicable alternatives suggested themselves, the risk was taken. The choice of antibiotics was confined to those generally having little clinical effect on non-specific urethritis. Broadspectrum antibiotics were avoided, and also penicillin (except in one case where the organisms were sensitive to this substance only) which, in vitro, adversely affects viruses of the trachoma-LGV group. Thin filter membranes (Courtauld or Gradocol, with average pore diameters of 0.5 to $1.0 \mu$ and $0.97 \mu$ respectively) were used to minimize the risk of losing viral particles by absorption on a filter pad. The procedure used for specimens from the first eight cases was as follows: the urethral washing was ground in a Ten Broeck tube to break up clumps of cells, and (except in Cases 5 and 6) divided into two parts. One half was filtered, and antibiotics were added to the other half (Table II). Eggs and cell cultures were then inoculated with the treated washings.

\section{Cases 1 to 8}

Results

Table II shows the results obtained with these specimens.

No virus-like inclusions were found in the stained urethral smears from these men, and no CPE or other cytological evidence of viral infection was demonstrable in any of the cell cultures. Some spherical and rod-shaped Castaneda-positive particles were found in yolk-sac impressions of some third and fourth pass eggs from the secretions of Case 2 but, as these disappeared in subsequent passes, their significance could not be assessed.

Modification in Technique and Results in Cases 9 to 14

Because of the negative results from the first eight urethral washings, those from the next six patients were treated in a slightly different way.

TABLE II

EXAMINATION OF URETHRAL SECRETIONS FOR VIRUSES

\begin{tabular}{|c|c|c|c|c|c|c|c|c|c|c|c|c|c|}
\hline \multirow{3}{*}{$\begin{array}{l}\text { Case } \\
\text { No. }\end{array}$} & \multicolumn{3}{|c|}{$\begin{array}{c}\text { Urethral Scraping Stained } \\
\text { with: }\end{array}$} & \multirow{3}{*}{\multicolumn{2}{|c|}{ Urethral Washing into: }} & \multicolumn{2}{|c|}{ Eggs } & \multicolumn{6}{|c|}{ Cell Cultures } \\
\hline & \multirow[b]{2}{*}{ Iodine } & \multirow[b]{2}{*}{ Giemsa } & \multirow[b]{2}{*}{ Castaneda } & & & \multirow{3}{*}{$\begin{array}{c}\begin{array}{c}\text { No. of } \\
\text { Passes } \\
*\end{array} \\
1\end{array}$} & \multirow{3}{*}{ 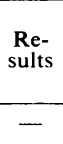 } & \multicolumn{2}{|c|}{$\mathrm{HeLa}$} & \multicolumn{2}{|c|}{ Thyroid } & \multicolumn{2}{|c|}{ Amnion } \\
\hline & & & & & & & & $\begin{array}{l}\text { No. of } \\
\text { Passes }\end{array}$ & $\begin{array}{c}\text { Re- } \\
\text { sults }\end{array}$ & $\begin{array}{l}\text { No. of } \\
\text { Passes }\end{array}$ & $\begin{array}{c}\text { Re- } \\
\text { sults }\end{array}$ & $\begin{array}{l}\text { No. of } \\
\text { Passes }\end{array}$ & $\begin{array}{l}\text { Re- } \\
\text { sults }\end{array}$ \\
\hline \multirow[b]{2}{*}{1} & \multirow[b]{2}{*}{-} & \multirow[b]{2}{*}{-} & \multirow[b]{2}{*}{ Not done } & \multirow[b]{2}{*}{ Fresh } & Filtered & & & 2 & - & \multicolumn{2}{|c|}{0} & 1 & - \\
\hline & & & & & $\begin{array}{l}+ \text { Streptomycin } \\
200 \mu \mathrm{g} . / \mathrm{ml} \text {. }\end{array}$ & \multicolumn{2}{|c|}{0} & \multicolumn{2}{|c|}{0} & \multicolumn{2}{|c|}{0} & 1 & - \\
\hline \multirow[b]{2}{*}{2} & \multirow[b]{2}{*}{-} & \multirow[b]{2}{*}{ - } & \multirow[b]{2}{*}{ Not done } & Fresh & Filtered & \multicolumn{2}{|c|}{0} & \multicolumn{2}{|c|}{0} & \multicolumn{2}{|c|}{ Not done } & 1 & - \\
\hline & & & & Frozen & $+\begin{array}{l}\text { Streptomycin } \\
1,000 \mu \mathrm{g} . / \mathrm{ml}\end{array}$ & 6 & - & 2 & - & 1 & - & 1 & - \\
\hline \multirow[b]{2}{*}{3} & \multirow[b]{2}{*}{ - } & \multirow[b]{2}{*}{-} & \multirow[b]{2}{*}{-} & Fresh & Filtered & 1 & - & \multicolumn{6}{|c|}{$<\longrightarrow$ Not done $\longrightarrow$} \\
\hline & & & & Frozen & $+\underset{500 \mathrm{u} . / \mathrm{ml}}{\text { Neomycin }}$ & 1 & - & 1 & - & $\begin{array}{l}\text { Not } \\
\text { Prin } \\
\text { Cult } \\
\text { Neg. }\end{array}$ & $\begin{array}{l}\text { issed } \\
\text { ary } \\
\text { res } \\
\text { tive }\end{array}$ & 1 & - \\
\hline & & & & Fresh & Filtered & & & 0 & & $<-$ & - Not & lone - & $\longrightarrow$ \\
\hline 4 & - & - & - & Frozen & $\begin{array}{l}\text { Streptomycin } \\
1,000 \mu \mathrm{g} . / \mathrm{ml}\end{array}$ & Not & lone & 1 & - & Not & one & 1 & - \\
\hline 5 & - & - & - & Frozen & $\begin{array}{l}+ \text { Streptomycin } \\
10,000 \mu \mathrm{g} . / \mathrm{ml} \\
+ \text { Neomycin } \\
10,000 \mathrm{u} . / \mathrm{ml} .\end{array}$ & 1 & - & 2 & - & 1 & - & 1 & - \\
\hline 6 & - & -- & - & Frozen & $+\underset{5,000 \mathrm{u} . / \mathrm{ml}}{\text { Penicillin }}$ & 1 & - & 1 & - & c & & 1 & - \\
\hline & & & & & Filtered & 1 & - & 1 & - & $<$ & $-\overline{N o t}$ & done - & $\rightarrow$ \\
\hline 7 & - & - & Not done & Frozen & $\begin{array}{l}\text { Streptomycin } \\
10,000 \mu \mathrm{g} . / \mathrm{ml}\end{array}$ & 1 & - & Not & lone & 1 & - & 1 & - \\
\hline & & & & & Filtered & 1 & - & 1 & - & $<<$ & - Not & done - & $\rightarrow$ \\
\hline 8 & - & - & Not done & Frozen & + Streptomycin & 1 & - & Not & lone & 1 & - & 1 & - \\
\hline
\end{tabular}

$-=$ Negative result. $\quad 0=$ Bacterial contamination.

* i.e. the number of passes excluding the primary cell cultures. 
As a majority of infections with non-specific urethritis seem to be acquired during sexual intercourse, an infective agent might never be exposed to daylight, and it might be that light would be lethal to it. To remove this possible source of inactivation, the washings from Cases 9 to 14 were collected into black bottles. Antibiotics were added to five of the specimens, and the sixth, which contained bacteria sensitive only to the tetracyclines, was put through a filter covered with black paper. Aliquot amounts of the washings were carefully added to the cell culture tubes under dark cloths. The cultures were incubated in the dark, and the condition of the cells ascertained by removing coverslips at intervals from inoculated and control tubes, and staining them.

Eggs were not inoculated with urethral washings from these patients, as it is necessary to expose the eggs to a certain amount of light during candling.

As Table III shows, four of these urethral samples gave negative results. In the cultures from Case 10, a CPE occurred in the HeLa cells. These became rounded and detached from the glass in the inoculated primary cultures but not in the control tubes; this effect was repeated in two passes but not in a third. A slight CPE in the primary thyroid cell cultures made from this washing did not appear in the pass to fresh thyroid cells, and the amnion cells in both primary culture and pass remained healthy, Some of the HeLa cells inoculated with urethral washing from Case 11 looked somewhat abnormal after 4 days' incubation; a pass from these produced two healthy and one degenerate-looking culture, but the latter, when passed again, did not damage fresh cells, and no similar effect was observed in thyroid and amnion cell cultures inoculated from the same washing.

It was suggested that the enzymes in the prostatovesicular secretion might predispose the epithelial lining of the urethra to infection. Prostato-vesicular fluid from Case 9 was added to his urethral washing before inoculation into cell cultures. The results in this case were also negative (see Table III). Further investigations along these lines were not carried out, because the time lag between the taking of the urethral washing on the patient's first attendance, and the collection of prostato-vesicular fluid a few weeks later, necessitated storing the washing at $-72^{\circ} \mathrm{C}$. during the interval-a procedure which it was wished to avoid.

\section{Further Modification in Technique and Results in Cases 15 to 20}

In a final effort to encourage the hypothetical virus to show itself, different types of cell culture were tried. Bearing in mind the success obtained by those

TABLE III

EXAMINATION OF URETHRAL SECRETIONS FOR VIRUSES

\begin{tabular}{|c|c|c|c|c|c|c|c|c|c|c|}
\hline \multirow{4}{*}{$\begin{array}{c}\text { Case } \\
\text { No. } \\
9\end{array}$} & \multicolumn{2}{|c|}{$\begin{array}{l}\text { Urethral Scrapings } \\
\text { Stained with: }\end{array}$} & \multirow{3}{*}{\multicolumn{2}{|c|}{ Urethral Washing into: }} & \multicolumn{6}{|c|}{ Cell Cultures } \\
\hline & \multirow[b]{2}{*}{ Iodine } & \multirow[b]{2}{*}{ Giemsa } & & & \multicolumn{2}{|r|}{ HeLa } & \multicolumn{2}{|r|}{ Thyroid } & \multicolumn{2}{|c|}{ Amnion } \\
\hline & & & & & $\begin{array}{l}\text { No. of } \\
\text { Passes }\end{array}$ & Results & $\begin{array}{l}\text { No. of } \\
\text { Passes }\end{array}$ & Results & $\begin{array}{l}\text { No. of } \\
\text { Passes }\end{array}$ & Results \\
\hline & - & - & Frozen & $\begin{array}{l}\text { + Prostatic fluid } \\
+ \text { Neomycin } \\
10,000 \text { u. } / \mathrm{ml} .\end{array}$ & 1 & - & 1 & - & 1 & - \\
\hline 10 & - & - & Frozen & $+\underset{20,000 \mu \mathrm{g} . / \mathrm{ml}}{\text { Streptomycin }}$ & 3 & $\begin{array}{l}\text { CPE in Primary } \\
\text { Cultures and } \\
\text { Passes } 1 \text { and } 2 \\
\text { Pass } 3 \text { Negative }\end{array}$ & 1 & $\begin{array}{l}\text { CPE in Primary } \\
\text { Cultures } \\
\text { Pass Negative }\end{array}$ & 1 & - \\
\hline 11 & - & - & Frozen & Filtered & 2 & $\begin{array}{c}\text { CPE in Primary } \\
\text { Cultures and } \\
\text { Pass } 1 \\
\text { Pass } 2 \text { Negative }\end{array}$ & 1 & - & 2 & - \\
\hline 12 & - & - & Frozen & $\begin{array}{l}\text { Streptomycin } \\
10,000 \mu \mathrm{g} . / \mathrm{ml} .\end{array}$ & & 0 & 1 & - & 2 & - \\
\hline 13 & - & - & Fresh & $\begin{array}{l}+ \text { Neomycin } \\
10,000 \mathrm{u} . / \mathrm{ml} . \\
+ \text { Streptomycin } \\
10,000 \mu \mathrm{g} / \mathrm{ml}\end{array}$ & 1 & - & & Not done & 1 & - \\
\hline 14 & - & - & Fresh & $\begin{array}{l}+ \text { Neomycin } \\
10,000 \mathrm{u} . / \mathrm{ml} . \\
+ \text { Streptomycin } \\
10,000 \mathrm{\mu g} . / \mathrm{ml}\end{array}$ & 1 & - & & Not done & 1 & - \\
\hline
\end{tabular}


working with the common cold virus (Hitchcock and Tyrrell, 1960; Tyrrell, Bynoe, Hitchcock, Pereira, and Andrewes, 1960), using human foetal cells, cell cultures prepared from human embryonic kidneys and lungs were used for the specimens from Cases 15 to 20. The washings from these six patients were also collected in black bottles and put into cell cultures as soon as possible (always within 1 hour) after having been taken from the patient. Table IV summarizes the results obtained with these specimens.

The only point of interest here was the very marked CPE in the lung cell cultures which had received urethral material from Case $16 ; 3$ days after inoculation, the medium in the inoculated tubes was markedly acid and very few cells were left on the glass. This was in striking contrast to the neutral medium and healthy monolayers in the control tubes. Numerous trichomonads were then discovered in the inoculated cultures, and these also appeared in a pass made to fresh lung cells. To investigate the possibility of some other agent besides the trichomonads causing this spectacular CPE, the following experiment was carried out:

The flagellates were killed by lowering the osmotic pressure of the culture fluid. When tonicity had been restored to the fluid by adding hypertonic saline, it was put into fresh foetal lung cell cultures. As no cytopathic changes were evident even after 32 days, it was assumed that the cell destruction in the original cultures was due to Trichomonas vaginalis alone.

\section{Discussion}

No virus was isolated from any of the urethral washings of the twenty patients with non-specific urethritis. These negative results fit in with the findings of others who have searched in vain for a viral agent responsible for this disease.

Failure to isolate any viruses at all from the urethral washings was interesting. Even though the causative agent of non-specific urethritis did not appear, the possibility of growing virus contaminants might have been expected. It is unlikely that this failure was due to a defect in the systems employed as, during the investigation, various viruses were isolated from other sources, using eggs and tissue cultures from the same stocks.

It may be that the cell types used were unsuitable for the isolation of a virus responsible for non-specific urethritis, or that other conditions were not optimal for its growth. It is possible, too, that the virus was growing in the cells without causing any CPE or providing other evidence of its presence.

There remains the possibility that we must look elsewhere than among the viruses for the cause of non-specific urethritis.

\section{Summary}

Urethral secretions from twenty men with nonspecific urethritis were examined for the presence of viruses.

TABLE IV

EXAMINATION OF URETHRAL SECRETIONS FOR VIRUSES

\begin{tabular}{|c|c|c|c|c|c|c|c|c|c|c|c|c|}
\hline \multirow{4}{*}{$\begin{array}{c}\text { Case } \\
\text { No. }\end{array}$} & \multicolumn{2}{|c|}{$\begin{array}{l}\text { Urethral Scrapings } \\
\text { Stained with: }\end{array}$} & \multirow{3}{*}{\multicolumn{2}{|c|}{ Urethral Washing into: }} & \multicolumn{8}{|c|}{ Cell Cultures } \\
\hline & \multirow{2}{*}{ Iodine } & \multirow[b]{2}{*}{ Giemsa } & & & \multicolumn{2}{|c|}{$\mathrm{HeLa}$} & \multicolumn{2}{|c|}{ Foetal Kidney } & \multicolumn{2}{|c|}{ Foetal Lung } & \multicolumn{2}{|c|}{ Others } \\
\hline & & & & & $\begin{array}{l}\text { No. of } \\
\text { Passes }\end{array}$ & Results & $\begin{array}{l}\text { No. of } \\
\text { Passes }\end{array}$ & Results & $\begin{array}{l}\text { No. of } \\
\text { Passes }\end{array}$ & Results & $\begin{array}{l}\text { No. of } \\
\text { Passes }\end{array}$ & Results \\
\hline & - & - & Fresh & $\begin{array}{l}+ \text { Neomycin } \\
2,000 \mathrm{u} . / \mathrm{ml} . \\
+ \text { Streptomycin } \\
2,000 \mu \mathrm{g} . / \mathrm{ml} .\end{array}$ & 1 & - & 1 & - & 2 & - & & \\
\hline 16 & - & - & , & $"$ & \multicolumn{2}{|c|}{ Not done } & 1 & - & \multicolumn{2}{|c|}{$\begin{array}{c}\text { CPE due to } \\
T . \text { vaginalis in } \\
\text { Primary Cultures } \\
\text { and Pass } 1 \\
\text { Pass } 2 \text { Negative }\end{array}$} & \multicolumn{2}{|c|}{$\left.1\right|^{2}-$} \\
\hline 17 & - & - &, & , & \multicolumn{2}{|c|}{ Not done } & 1 & - & 1 & - & \multicolumn{2}{|c|}{$\begin{array}{l}\text { Foetal Intestine } \\
\text { Primary Cultures } \\
\text { Negative } \\
\text { Not passed }\end{array}$} \\
\hline 18 & - & - & $\bar{n}$ & ", & 1 & - & 1 & - & 1 & - & & \\
\hline 19 & - & - & $\bar{n}$ & , & 1 & - & 1 & - & 1 & - & & \\
\hline 20 & - & - & , & , & 1 & - & 1 & - & 1 & - & & \\
\hline
\end{tabular}


Details of the methods used (staining of urethral smears, egg inoculations, and cell cultures) are given.

No viruses were isolated from any of the specimens.

I am glad to have this opportunity of thanking Prof. C. F. Barwell of the Department of Bacteriology, the London Hospital Medical College, both for providing facilities in the Department for the performance of this work, and for his unstinted advice during its course. I acknowledge with much gratitude the help in acquiring knowledge of virological techniques given me by Dr. Sylvia Reed of the same Department. I should like to thank Mr. A. J. King of the Whitechapel Clinic, the London Hospital, for making available to me material from the patients, and Dr. John Hancock for his enthusiastic co-operation in collecting the specimens. Dr. $\mathrm{H}$. E. M. Kay of the Royal Marsden Hospital kindly supplied the foetal organs from which the embryonic cell cultures were prepared. To Mr. W. Finch, Senior Technician in the Bacteriology Department of the London Hospital, I remain indebted for constant and willing help on technical matters.

This work was carried out under the auspices of the Medical Research Council Working Party on Nonspecific Urethritis with the financial assistance of a grant from the United States Public Health Service.

\section{REFERENCES}

Csonka, G. W., and Furness, G. (1960). Brit. J. vener. Dis., 36, 181.

Feinberg, J. G., and Whittington, M. J. (1957). J. clin. Path., 10, 327.

Ford, D. K. (1956). Brit. J. vener. Dis., 32, 184. (1958). Ibid., 34, 53.
Fritsch, H., Hofstätter, A., and Lindner, K. (1910). v. Graefes Arch. Ophthal., 76, 547. (Cited by Harkness, 1950.)

Gey, G. O., Bang, F. B., and Gey, M. K. (1954). Ann. N.Y. Acad. Sci., 58, art. 7, p. 976.

Gilkes, M. J., Smith, C. H., and Sowa, J. (1958). Brit. J. Ophthal., 42, 473.

Hanks, J. H. (1949). Proc. Soc. exp. Biol. (N. Y.), 71, 328.

Harkness, A. H. (1950). "Non-gonococcal Urethritis". Livingstone, Edinburgh.

Hitchcock, G., and Tyrrell, D. A. J. (1960). Lancet, 1, 237.

Jones, B. R., Collier, L. H., and Smith, C. H. (1959). Ibid., 1,902 .

Klieneberger-Nobel, E. (1959). Brit. med. J., 1, 19.

Lindner, K. (1910). Wien. klin. Wschr., 23, 283. (Cited by Harkness, 1950.)

Pulvertaft, R. J. V., Davies, J. R., Weiss, L., and Wilkinson, J. H. (1959). J. Path. Bact., 77, 19.

Reed, S. E. (1961). Personal communication.

Siboulet, A. (1955). Brit. J. vener. Dis., 31, 235.

Thygeson, P., and Mengert, W. F. (1936). Arch. Ophthal. (Chicago), 15, 377.

- and Stone, W. (1942). Ibid., 27, 91.

Tyrrell, D. A. J., Bynoe, M. L., Hitchcock, G., Pereira, H. G., and Andrewes, C. H. (1960). Lancet, 1, 235.

Pathogenèse virale de l'urétrite non-gonococcique

\section{RÉSUMÉ}

Ou chercha les virus dans les sécrétions urétrales de 20 hommes atteints d'urétrite non-gonococcique.

Les méthodes employées (coloration des frottis urétraux, inoculations à l'oeuf, et cultures de cellules) sont décrites.

Aucun virus ne fut isolé d'aucun spécimen. 